The average size of certain important fishes, for example, plaice, soles and haddocks, in the North Sea landings has been materially-perhaps even alarmingly-reduced. In other words, an increased proportion of the eatches now consists of small fish. For full details of this and other changes in the nature of the landings the reader must consult the tables as set out in extenso in the Bulletin. But certain important details concerning the North Sea plaice may be usefully included here.

It is now generally known that the percentage of small plaice landed in England fell rapidly during the Great War. From 45-50 per cent in the immediate pre-War years, it dropped to 24 per cent in 1915 and even fell so low as 7 per cent in 1919. After that year, it rose again, and has kept a steady average of about 70 per cent from 1925 onwards. Thus, during the War and for several years afterwards, the English market was supplied with plaice larger on an average than either before or afterwards. Temporary abandonment of 'small fish' grounds is not regarded by the compiler of the Bulletin as a satisfactory explanation of this; nor does he regard with favour the more usual suggestion that the North Sea plaice had a respite from too intensive fishing during the War so that a larger number lived longer, grew bigger and eventually came into the market until the accumula. tion dwindled. On this point, attention is directed to the significant fact that, in England, the proportion of small plaice began to fall in the year 1914, before any great restriction of fishing grounds had taken place and long before the fish on any closed area had had time to grow. It is interesting to note that the haddock showed no sign of any post-War period of comparatively large fish, that is, there was no benefit from partial closure of the North Sea grounds.

With regard to the other plaice-producing countries, we find that in the seven years 1907-13 the mean percentage of small plaice was 47 per cent in England; 83 per cent in Germany ; 87 per cent in Holland. In the seven years 1927-33 the corresponding figures are given as 74 per cent, 90 per cent and 95 per cent. Whatever be its cause or causes, this great increase in the percentage of small plaice-and other fishes-in the North Sea catches is a phenomenon the effect of which on the future of the fisheries of Great Britain and other countries seems likely to be of extreme importance.

\section{Uplift Pressure on Dams}

$\mathrm{W}^{\mathrm{u}}$ EN a dam is built on porous strata such as generally exist at the beds of rivers, there is a flow through these porous strata under the masonry from the upstream to the downstream side. Accom. panying this, there will be a pressure acting upwards on the masonry floor. An accurate knowledge of this uplift pressure and of the nature of its distribution is of fundamental importance for the purpose of designing a dam. There have been many attempts to investigate by direct measurements from models the way in which this pressure varies with different forms of design.

The usual method of building a tank provided with holes for manometers and filled with sand to represent the subsoil strata and of arranging a model of the dam with a suitable head of water upstream involves a very large number of readings, and is most laborious. Observing the analogy between Ohm's law for the conduction of electricity and Darcy's law for the conduction of water through porous media, N. N. Pavlovsky in 1921 suggested that an electrical method could be employed for studying the subsoil pressures under dams (Proceedings of the International Congress on Dams, 1933). In a paper to the Indian Academy of Sciences (Proc., 2, No. 1, July 1935), Mr. G. Ram, Dr. V. I. Vaidhianathan and Dr. E. McKenzie Taylor, of the Irrigation Research Institute, Lahore, have described their investigations and the methods and apparatus used in determining to what extent this suggestion could be made the basis of a successful attack on the problem of subsoil flow under dams.

In the several cases examined of simple impervious floors with and without sheet piling, the curves obtained by the direct and the indirect methods and by theoretical calculations agreed so closely as to give support to the claim of the authors that the indirect electrical method is trustworthy. They consider that earlier failures have been due to faulty technique, and assert that the fact that the potential distribution in conductors has been shown to be of the same form as the pressure distribution in the subsoil under dams, establishes the mathematical foundation for designs of these works, and, as such, should be considered a great advance on our existing knowledge.

\section{Educational Topics and Events}

BIRmingham.-The Poynting chair of physics, which will be vacated by the retirement at the end of the present session of Prof. S. W. J. Smith, is to be filled by the appointment of Dr. M. L. Oliphant, assistant director of research in physics at the Cavendish Laboratory, Cambridge.

Mr. J. W. Drinkwater has been appointed lecturer in mechanical engineering.

Cambridge.-C. H. Thompson, Queens' College, has been appointed Gurney lecturer in forestry, and J. H. Lockhead, Christ's College, University demonstrator in zoology.

In its annual report, the Committee of Management of the Scott Polar Research Institute states that the Oxford University Expedition to North East Land before its departure, and the Oxford University Ellesmere Land Expedition 1934-35, since its return, have both made use of the facilities of the Institute, which have also been of service to the forthcoming Cambridge expeditions to Iceland, members of which have been at work for some time in the library and map room.

Durham.-At the Convocation to be held on June 30 , the honorary degree of D.Sc. will be conferred on Mr. G. S. Baker, superintendent of the William Froude Laboratory at the National Physical Laboratory, and the honorary degree of D.Litt. on Mr. Robert Steele, editor of the works of Roger Bacon and other medieval literature.

OxFord.-On June 6, the honorary degree of D.Litt. was conferred on Mr. E. A. Lowe, University reader in palæography. At Encænia on June 24, the honorary degree of D.Sc. will be conferred on Prof. E. D. Adrian, Foulerton research professor of the Royal Society. Among those who will then receive honorary degrees of D.C.L. are Prof. Gilbert Murray and $\mathrm{Mr}$. Anthony Eden. 